\title{
Museums Association
}

\author{
Annual Conference at Leeds
}

$\mathrm{T}$

HE forty-seventh annual conference of the Museums Association was held at Leeds on July 6-10. The meetings were held in the Museum, and the usual trade exhibition and members' exhibits were in the entrance hall of the Art Gallery. The conference attracted a record attendance; more than three hundred members and delegates met under the presidency of Sir Eric Maclagan, director of the Victoria and Albert Museum.

Sir Eric, in his presidential address on "Museums and the Public", gave a summary of the various services afforded children and adults by the museums. $\mathrm{He}$ is not convinced that children's museums, as separate entities, are a wise ideal, and preferred that children's exhibits should constitute a bait rather than a permanent diet. He would like to see the abolition of many petty restrictions upon adults, such as the ban upon walking-sticks and umbrellas; yet, on the other hand, there is the danger of coddling the public owing to the excellent seats, gardens, refreshment rooms and guide lecturers now at the service of the visitor. Too little, perhaps, is being left to the public, and museums are not peep-shows and need not degenerate into them. In view of the little that museums do which has any real news value, Sir Eric thinks that great credit should be given to the newspapers, which are so often among the museum's best friends.

Following the presidential address, Col. Kitson Clark told the interesting story of the various Leeds museums and the persons responsible for their foundation. The morning session concluded with an address by Sir Harry Lindsay, director of the Imperial Institute, upon the various methods of visual instruction developed and used for adults and children in the Institute.

In the afternoon, Mr. F. R. Worts, headmaster of the City of Leeds School, dealt with museums and secondary schools, a subject which elicited a lively discussion, from which it was apparent that too much is expected from the museums and too little co-operation offered by the schools. The session concluded with a somewhat detailed, but important, discussion on nomenclature in natural history collections, opened by Dr. F. J. North, and a description of the new Perth Museum and Art Gallery by its director. Mr. J. Ritchie, who illustrated his remarks with lantern slides and a cinematograph film.

The opening paper on Wednesday morning was by Mr. Leigh Ashton, of the Victoria and Albert Museum, who described the display methods he used so successfully in arranging the recent Chinese Art Exhibition at Burlington House. He was followed by Mr. Philip Hendy, director of Leeds City Art Gallery, who had much to say about the lack of civic encouragement to art galleries. He deplored the lack of visual imagination at the present time and the tendency to "think in print". He regrets the decay of craftsmanship, and looks upon the art gallery as a remedy to industrialism, but he thinks that art galleries might profitably exhibit more manufactured objects. Mr. S. F. Markham followed with an account of the museums in India, based upon his recent survey, and the morning session concluded with an important discussion on the copyright of paintings in museums and art galleries.

Thursday morning was occupied largely by the annual general meeting but there was a vigorous discussion on the future of the Association. Finally Dr. Mortimer Wheeler read an account, by Mr. Iliffe of the folk museum movement in Palestine.

Excursions were made to various places of interest including Temple Newsam Mansion, Kirkstall Abbey, Harewood House and Fountains Abbey.

The new president of the Association is Alderman Charles Squire, of Leicester, and the next conference will be held at Newcastle-upon-Tyne.

\section{Society of Chemical Industry}

\section{Annual Meeting at Liverpool}

\section{$\mathrm{T}$} HE programme of the annual meeting of the Society of Chemical Industry at Liverpool, July 6-10, in itself provides an excellent illustration of the way in which chemical industry is linked up with almost every aspect of our national life, and of the extent to which chemical science enters into questions not only of industry but also of transport, food supply and the like.

The Messel Memorial Lecture, "Works as I have seen them Grow", delivered by Sir Robert Mond on July 8, gave an impressive account of the development of the Winnington works of Brunner, Mond and Co., as well as of the Mond Nickel Co. and the
Mond Gas Companies, which well illustrates the creative power of science in developing new industries or adapting old ones to changed conditions. It might also be regarded as a dissertation on the theme that the mental process of pure research, the way of asking Nature the right question and of obtaining adequate responses, is as applicable to applied as to pure science. Knowledge of progress depends on trustworthy and continuous measurements of all the many factors involved, and these measurements can be effected as well on a works as on a laboratory scale, and with intelligent designing no great or specially expensive methods are required. Acting on 